Erika Loučanová; Miriam Olšiaková

\title{
DISTRIBUTION FLOW IDENTIFICATION IN COOPERATION AND SUPPORT FOR ECOLOGICAL INNOVATION INTRODUCTION IN SLOVAK ENTERPRISES
}

\author{
Erika Loučanová \\ Technical University in Zvolen, The Faculty of Wood Sciences and Technologies, Department of marketing, trade and \\ world forestry, T. G. Masaryka 24, 96053 Zvolen, Slovak republic, EU, loucanova@ tuzvo.sk (corresponding author) \\ Miriam Olšiaková \\ Technical University in Zvolen, The Faculty of Wood Sciences and Technologies, Department of marketing, trade and \\ world forestry, T. G. Masaryka 24, 96053 Zvolen, Slovak republic, EU, olsiakova@ tuzvo.sk
}

Keywords: ecological innovations, distribution flow, cluster analysis

Abstract: Innovations play an important role in achieving success of a company in a strong competitive environment. It is not sufficient just to innovate, but the more emphasis is placed on the creation of innovations implemented on the principle of sustainable development. This is the reason why ecological innovations are so important and why they have become the object of our survey which results are the topic of this paper. The paper presents the results of the survey monitoring the state of knowledge and usage of selected incentives within the distribution flows in cooperation and support for ecological innovation introduction in Slovak enterprises. The survey was realized by questioning in Slovak enterprises. The sample consisted of 517 enterprises that were selected by random selection from the population sample of the Slovak Republic. The surveyed questionnaires were processed into the database and subsequently evaluated quantitatively. Through a cluster analysis they were processed by cluster analysis in the STATISTICA program. Following the results, we can claim that in cooperation and support for ecological innovation introduction in Slovak enterprises, the distribution flows are mainly focused on sectoral innovation activity and less on regional and national innovation activity. The results show the difference in the use of selected incentives within the distribution channels in cooperation and support for the ecological innovation introduction in Slovak enterprises, which according to several authors is not a market failure, but from the point of view of a system approach to innovation, it is so called "innovation paradox".

\section{Introduction}

In a strong competitive environment in the market, the innovation presents an important tool for competitiveness. To implement innovation as a tool of competitiveness, it is important not only to master the implementation of the innovation process, but also to find inventions, financial resources, and many other aspects that are the incentives for successful innovation application in the market. They enter the innovation process both at the beginning but also during the implementation of innovation as a source. The sources representing the innovation capacity of the company are reimbursed by internal as well as external sources.

As stated by Straka et al. [1] the distribution logistics providing the physical, organizational and information link between resources and the innovation process plays an important role in order to ensure the most appropriate way of selecting, analysing and transporting these resources during the innovation process.

However, in the last period, it is not enough just to innovate, but the more emphasis is placed on the creation of innovations implemented on the principle of sustainable development, thus representing ecological innovation. The EU [2] also presents, it is necessary to realize ecological innovations that increase the protection of the environment and the competitiveness of EU industry, introducing technologies, processes and business models that use resources more effective.

Innovation Management implements ecological innovation through innovation of sustainable resources use and materials from the environment, including the growing importance of socio-economic development [3-6].

The interconnection of innovation management within the sustainable development policy is ensured by a distribution policy that links incentives, physical, organizational and information interconnection among the different activities of the innovation process.

The Innovation Management in this understanding is a dynamic factor of the economy, focusing on the farreaching commercial use of innovation for the future direction of enterprises within an environmental-oriented strategy.

Such an understanding of innovation management in conjunction with distribution logistics, linking incentives, physical, organizational and information interconnection in the innovation process, regarding globalization trends representing a modern distribution philosophy, is based on factors of time, spatial structures, transport market boom, cluster formation [7]. 
DISTRIBUTION FLOW IDENTIFICATION IN COOPERATION AND SUPPORT FOR ECOLOGICAL INNOVATION INTRODUCTION IN SLOVAK ENTERPRISES

Erika Loučanová; Miriam Olšiaková

For better overview in these factors influencing innovation and thus ecological innovation, it is necessary to know the chain of information, incentives and other factors within the distribution flows of the innovation process for their more efficient use, fulfilling the EU's objectives.

The EU's goal is to change Europe into a low-carbon economy that effectively uses resources. Environmental technologies are an important part of the EU economy [2].

Their annual turnover is 320 billion euros, and since 2004 they have reached 8 percent annual growth. EU share presents one-third of the world market that could double to more than $€ 2200$ billion by 2020 [2].

The European Union promotes ecological innovation through a range of programs and policies. Within the implementation of ecological innovations in enterprises, these programs and policies are projected into incentives that can be of a different nature at national level, such as subsidies from ministries, the Slovak Business Agency, through stimuli at regional level (such as clusters, respectively Business Angels) and at sector level in the form of contractors and clients.

In addition, the incentives for innovations at all levels can have a different form. This paper presents selected ones. All of these incentives focus on the stimulus of ecological innovations and obstacles to their realization.

Therefore, this paper is aimed at the identification of distribution flows in cooperation and support for the ecological innovation introduction in Slovak enterprises. with focus on external incentives of ecological innovation.

\section{Methodology}

The methodology of the paper is based on the questioning in Slovak enterprises. The sample consisted of 517 enterprises which were chosen by random selection from the population sample of the Slovak Republic. The sample of respondents was determined at a confidence level of $95 \%$, with a tolerance error of $+/-7 \%$ of the standard deviation of 0.5 , which at the given data represents the value of 196 respondents. The survey was realized both personally and electronically. 517 respondents fulfill conditions given by determined confidence level, standard deviation, and margin of error.
The survey was carried out through a questionnaire consisting of several parts, such as identification data, ecological innovation and their implementation in companies in Slovakia. The last part was aimed at distribution flows monitoring in cooperation and support for ecological innovation introduction in Slovak enterprises.

The questioning was implemented electronically, where we did not validate the position of the respondent representing the enterprise, but we assume that persons at lower positions like a manager would not have enough information on the issue. The surveyed questionnaires were processed into the database and subsequently evaluated quantitatively. Through a cluster analysis they were processed in the STATISTICA program. The cluster analysis was used for the evaluation regarding the determined survey objective, to monitor the clusters of information flows in cooperation and support for ecological innovation introduction in Slovak enterprises. Rimarčík [8] claims that the cluster analysis deals with how objects (statistical units) should be divided into groups to obtain the biggest similarity within the groups and the biggest difference among the groups. Within the algorithms of agglomerative hierarchical clustering we used the Ward's method that combines the clusters in which the increment of the total intragroup sum of squared deviations of individual values from aggregate diameters is minimal.

\section{Result and discussion}

Following the data obtained from the survey database, quantitative data evaluation shows that in a sample of respondents - Slovak enterprises - the distribution flow in cooperation and support for ecological innovation introduction is oriented mainly towards the sectoral level (see Table 1). Contractors have the largest representation from what follows mainly strong sectoral innovation activity and the support of ecological innovation in sectors. We understand clients as customers who can be represented by final consumers but also by any personal or corporate entity representing other processors, sales agents etc.

Table 1 Matrix of length

\begin{tabular}{|l|c|c|}
\hline $\begin{array}{l}\text { Selected incentives within distribution flows in cooperation and support for } \\
\text { ecological innovation introduction in Slovak enterprises }\end{array}$ & Quantity & $\%$ \\
\hline Contractors & 257 & 49.71 \\
\hline Clients & 127 & 24.56 \\
\hline Other .. (agencies, innovations centres etc.) & 59 & 11.41 \\
\hline Ministries & 47 & 9.09 \\
\hline Clusters & 12 & 2.32 \\
\hline Business Angels & 12 & 2.32 \\
\hline Slovak Business Agency & 3 & 0.58 \\
\hline
\end{tabular}


Erika Loučanová; Miriam Olšiaková

Subsequently, the data from the database were analysed by cluster analysis using the STATISTICA program (Figure 1). On the basis of more significant cluster diversity which has occurred at the 200 connection distance, where in the Euclidean distance among observed objects values have significantly increased. Regarding thus determined level we have identified two clusters.
Contractors and clients create a separate cluster 2 from the point of view of selected incentives within the distribution flows in cooperation and support for ecological innovation introduction in Slovak enterprises, which is specific due to its superiority in terms of other selected stimuli usage that form the second cluster.

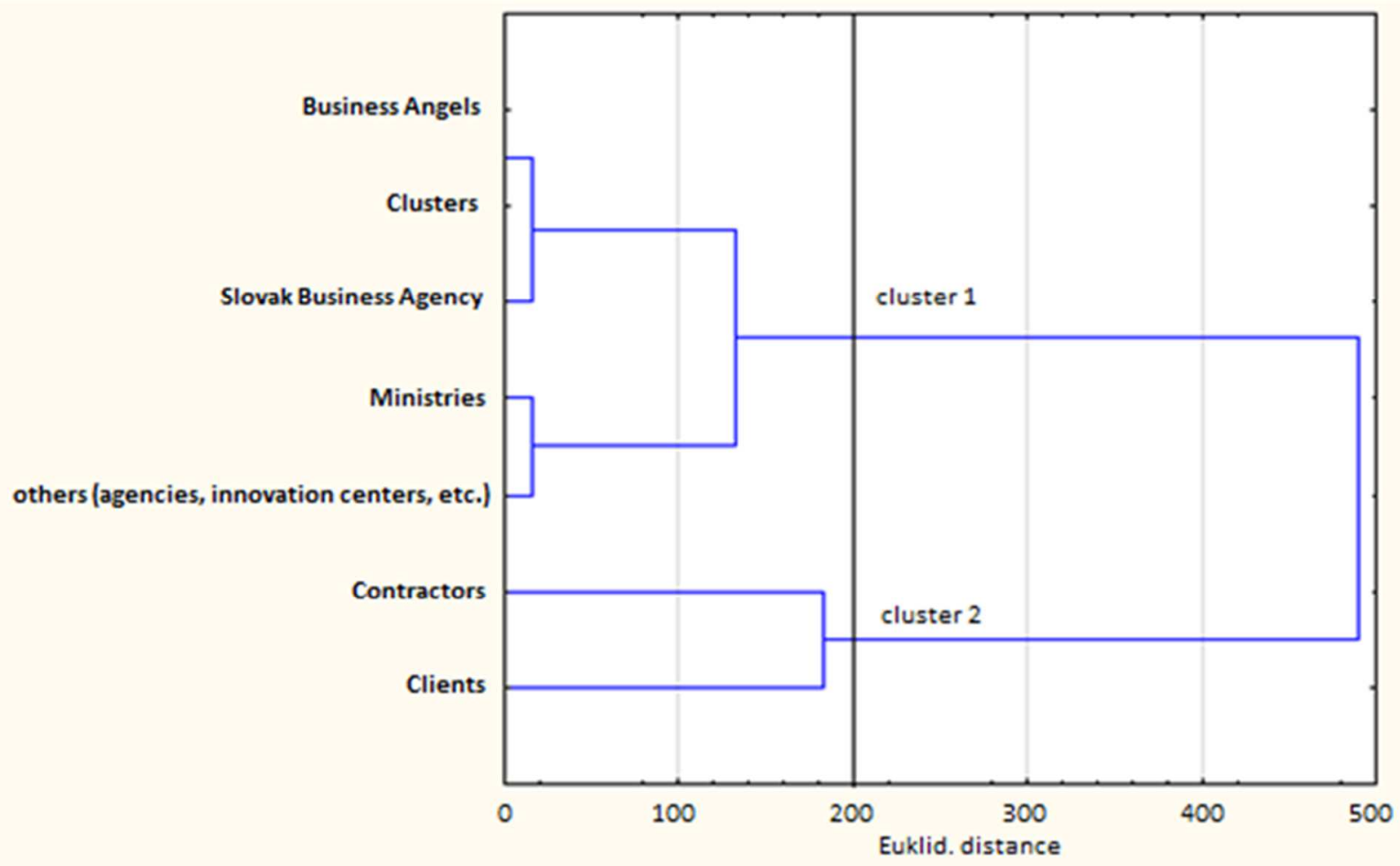

Figure 1 Cluster analysis of distribution flows to stimulus in cooperation and support for ecological innovation introduction in Slovak enterprises

Source: Own processing in STATISTICA program

So the cluster analysis pointed out to the fact how the objects (the selected incentives within the distribution flows in cooperation and support for the ecological innovations introduction in Slovak enterprises) are divided into groups to receive the greatest similarity within the groups and the greatest difference among the groups in terms of their use by enterprises to support the introduction of ecological innovation.

The first cluster groups selected incentives within distribution flows in cooperation and support for ecological innovation introduction in Slovak enterprises such as Business Angeles, Clusters, Slovak Business Agency, Ministries and others. This cluster of selected stimuli within the distribution flows in cooperation and support for ecological innovation introduction in Slovak enterprises is known and used in the business environment, but less than selected stimuli in the cluster 2 .

The second cluster consists of contractors and clients, who according to the results presented in the Figure 1, represent the greatest incentives within the distribution flows in cooperation and support for ecological innovation introduction in Slovak enterprises.

Following the results, we can claim that in cooperation and support for ecological innovation introduction in Slovak enterprises, the distribution flows are mainly focused on sectoral innovation activity, because the mainly used incentives for support and cooperation for ecological innovation are contractors and clients representing the sectoral innovation activities, and less on regional and national innovation activity because in our survey they are presented by other incentives for cooperation and support and ecological innovations.

The results show the difference in the use of selected incentives within the distribution channels in cooperation and support for the ecological innovation introduction in Slovak enterprises, which according to several authors $[9,10]$ is not a market failure, but from the point of view of a system approach to innovation, it is so called "innovation paradox". Oughton et al. [11] describes an innovation paradox as a discrepancy among the relatively 
Erika Loučanová; Miriam Olšiaková

higher need to spend resources on innovation and the relatively lower capacity and ability to absorb these resources. As Skokan [9] states, this issue is weakly elaborated. However, optimization of this state can be achieved by approaching the Focal Model, which presents combination of bottom-up and top-down approaches to planning and subsequent co-ordination to support innovation within the innovation system. According to EuroEkonóm [12] and Repková-Štofková [13] the Focal Model incorporates both aspects of planning (bottom-up and top-down), where the first one allows using creativity and potential of individuals (enterprises in need of innovation support) and the second one applies effective political processes (innovation system management). This is the way to prevent innovation paradoxes. Based on the given findings and literature analysis by inference we propose to develop innovations support bottom up, because the sectoral level, cooperation among enterprises, contractors and clients presents the strongest basis.

\section{Conclusions}

Regarding the results of the survey, the paper evaluates the state of knowledge and usage of selected incentives within the distribution flows in cooperation and support for ecological innovation introduction in Slovak enterprises. Based on the data obtained from the randomly selected sample of respondents, the highest activity of innovation support has been noticed by contractors and clients at sectoral level. Other stimuli from the cluster analysis point of view are in a cluster characterized by a low influence on the implementation of ecological innovation in Slovak enterprises, pointing to an innovation paradox concentrating on barriers when they are used. Therefore, in the future, it is important to focus on the barriers of the innovative capacities for development of ecological innovation at all levels of the innovation system and to implement measures to improve the use of these capacities. In the context of concentration on barriers to improve the use of mentioned capacities it is appropriate to implement the Focal Model approach to plan and coordinate innovation support, using both its aspects (bottom-up and top-down) and by their optimization to prevent innovation paradoxes.

\section{Acknowledgement}

This article was supported by the Scientific Grant Agency of the Ministry of Education, Science, Research and Sport of the Slovak Republic and the Slovak Academy of Sciences. This paper is an output of the Grant No $1 / 0674 / 19$, "Proposal of a model for the ecological innovation integration into the innovation process of companies in Slovakia in order to increase their performance".

\section{References}

[1] STRAKA, M., MALINDŽÁK, D., STRAKOŠ, V., JANÁČEK, J., VIESTOVÁ, K., MARASOVÁ, D., ŠADEROVÁ, J., PETRAŠŠSOVITŠOVÁ, B., TAKALA, J., HELO, P., KAUPPINEN, P., BALOG, M.: Distribučná logistika, Košice, Expres Publicity, 2005. (Original in Slovak)

[2] ŽIVOTNÉ PROSTREDIE: Využívanie inovácií. Online, Available: http://ec.europa.eu/environment/ba sics/green-economy/innovation/index_sk.htm [21 Dec 2018], 2018. (Original in Slovak)

[3] KOLLÁR, V., BROKEŠ, P.: Environmentálny manažment, Bratislava, SPRINT, 2005. (Original in Slovak)

[4] LOUČANOVÁ, E., TREBUŇA, P.: Eko-inovácie ako nástroj konkurencieschopnosti, Transfer inovácií, Vol. 29, pp. 76-80, 2014. (Original in Slovak)

[5] LOUČANOVÁ, E.: Inovačné analýzy a stratégie, Zvolen, Technická univerzita vo Zvolene, 2016. (Original in Slovak)

[6] TREBUNA, P., PETRIKOVÁ, A., PEKARČÍKOVÁ, M.: Influence of physical factors of working environment on worker's performance from ergonomic point of view, Acta Simulatio, Vol. 3, No. 3, pp. 1-9, 2017.

[7] ŠULGAN M., GANP J., MAJERČÁK J.: Postavenie dopravy v logistike, Žilina, Žilinská univerzita, 2008. (Original in Slovak)

[8] RIMARČÍK, M.: Zhluková analýza., Online, Available: http://rimarcik.com/navigator/ca.html [22 Nov 2018], 2018. (Original in Slovak)

[9] SKOKAN, K.: Innovation Paradox and Regional Innovation Strategies, Journal of Competitiveness, Vol. 2010, No. 2, pp. 30-46, 2010.

[10] ADÁMEK, P., CSANK, P., ŽÍŽALOVÁ, P.: Regionální inovační systémy a jejich veřejná podpora, Working Paper CES VŠEM, Vol. 2007, No. 7., 2007. (Original in Czech)

[11] OUGHTON, CH., LANDABASSO, M., MORGAN, K.: The Regional Innovation Paradox: Innovation Policy and Industrial Policy, Journal of Technology Transfer, Vol. 2002., No. 27, pp. 97-110, 2002.

[12] EUROEKONÓM: Prístup zdola - nahor (Ohniskový model), Online Available: https://www.euroekonom. sk/manazment/manazment-zmien/pristup-zdola$\%$ E2\%80\%93-nahor-ohniskovymodel/ [20 Jan. 2019], 2019. (Original in Slovak)

[13] REPKOVÁ ŠTOFKOVÁ, K.: Využitie znalostného manažmentu na podporu konkurencieschopnosti, Manažment a siet’ové podnikanie vo vedomostnej ekonomike, KEGA 070ŽU-4/2011, pp. 7-24, 2013. (Original in Slovak)

Review process

Single-blind peer review process. 